\title{
BIOKONTROL IKAN PEMANGSA JENTIK DALAM PEMBERANTASAN VEKTOR NYAMUK PENYEBAB DEMAM BERDARAH DANGUE (DBD) di KOTA PAREPARE
}

\section{Biocontrol of fake market fishing in eradication Mosquito vectors causing dangue blood fever (dhf) In parepare city}

\author{
Rahmi $^{1}$, Rahmi Amir ${ }^{2}$, Usman $^{3}$ \\ Fakultas Ilmu Kesehatan Universitas Muhammadiyah Parepare \\ (rahmibasri95@gmail.com/082248595284)
}

\begin{abstract}
ABSTRAK
Demam Berdarah Dengue (DBD) merupakan penyakit yang disebabkan oleh virus dan ditularkan oleh nyamuk Aedes aegypti yang masih menjadi masalah kesehatan masyarakat di Indonesia. Penyakit ini menyerang semua kelompok umur dan muncul setiap tahun. Pengendalian DBD dilakukan dengan memanfaatkan ikan predator jentik seperti ikan cupang (Betta spp). Tujuan penelitian adalah untuk mengetahui perbedaan memangsa dari ikan cupang (betta spp) berdasarkan variasi ukuran panjang badan dalam memangsa jentik nyamuk Aedes aegypti. Jenis penelitian ini adalah eksperimental semu dengan desain Rancangan Acak Lengkap (RAL) menggunakan uji Anova. Sampel adalah ikan cupang (Betta spp) dengan kelompok ukuran S (2,5-3,4 cm), M (3,5-5 cm) dan L (5,5 cm keatas). Hasil penelitian, menunjukkan ikan cupang ukuran L paling efektif dalam memangsa jentik dengan rata-rata memangsa 48,78 ekor dalam 15 menit dari pada ikan cupang ukuran S dengan rata-rata memangsa 36,50 ekor dalam 15 menit dan ikan cupang ukran $\mathrm{M}$ rata-rata memangsa 44,78 ekor dalam 15 menit. Hasil analisis menunjukkan ada perbedaan memangsa dari ikan cupang berdasarkan variasi ukuran panjang badan dengan $(\mathrm{p}=0,00)$. Disarankan untuk penanggulangan nyamuk Aedes aegypti dapat dilakukan dengan cara biologi yaitu dengan memanfaatkan ikan pemangsa jentik seperti ikan Betta spp.
\end{abstract}

\section{Kata Kunci: Betta spp, Ukuran, Jentik Aedes aegypti.}

\begin{abstract}
S
Dengue Hemorrhagic Fever (DHF) is a disease caused by a virus and transmitted by the Aedes aegypti mosquito which is still a public health problem in Indonesia. This disease attacks all age groups and appears every year. DHF control is carried out by using larvae predator fish such as Betta fish (Betta spp). The aim of the study was to determine differences in prey from betta fish (betta spp) based on variations in body length in preying on Aedes aegypti mosquito larvae. This type of research is a quasi-experimental design with a completely randomized design (CRD) using the ANOVA test. Samples were Betta fish (Betta spp) with S size groups $(2.5-3.4 \mathrm{~cm}), M(3.5-5 \mathrm{~cm})$ and L $(5.5 \mathrm{~cm}$ and above). The results of the study, showed that L-size betta fish was most effective in eating larvae with an average prey on 48.78 tails in 15 minutes compared to $S$ size betta fish with an average prey of 36.50 tails in 15 minutes and betta fish in average $M$ prey on 44.78 tails in 15 minutes. The results of the analysis showed that there were differences in prey from betta fish based on variations in body length size $(p=0.00)$. It is recommended that the prevention of Aedes aegypti mosquitoes can be carried out by biological means by utilizing larvae of predators such as Betta spp.
\end{abstract}

Keywords: Betta spp, Size, wiggle Aedes aegypti. 


\section{PENDAHULUAN}

Masalah kesehatan yang dihadapi saat ini yaitu adanya peningkatan angka kesakitan bahkan kematian yang diakibatkan oleh penyakit yang ditularkan oleh nyamuk, di antaranya penyakit Demam Berdarah Dengue (DBD). Penyakit ini disebabkan oleh virus dengue, yang ditularkan melalui gigitan nyamuk Aedes aegypti.

Tinggi rendahnya angka kematian karena penyakit DBD ini berhubungan dengan tinggi rendahnya populasi nyamuk Aedes aegypti sebagai vektor penyakit tersebut. Semakin tinggi populasi nyamuk maka jumlah penderita akan semakin bertambah. ${ }^{1}$ Tercatat bulan Januari sampai Maret 2018 ada sebanyak 6 kasus DBD pada wilayah kerja Puskesmas Lapadde Kota Parepare.

Pengendalian penyakit DBD di Indonesia paling sering dilakukan dengan cara kimiawi menggunakan insektisida golongan organofosfat (malation dan temefos) dan abate untuk menurunkan kepadatan vektornya. Malation dan temefos selalu digunakan dalam program nasional pengendalian DBD di indonesia sejak tahun 1970-an. Penggunaan larvasida sintetis seperti temefos adalah salah satu upaya pengendalian vektor nyamuk Aedes aegypti di tahap jentik, tetapi pemanfaatan temefos secara terus menerus dan berulang merupakan faktor risiko terjadinya resistensi. ${ }^{2}$

Untuk mencegah terjadinya resistensi nyamuk terhadap insektisida diperlukan cara pengendalian alternatif yang lebih ramah lingkungan dan aman bagi kesehatan. ${ }^{3}$ Dalam upaya pengendalian vektor DBD, pengendalian secara hayati (biological control) dapat menjadi alternatif. Biological control adalah upaya pengendalian dengan menggunakan musuh alaminya untuk mengurangi populasi organisme, dalam hal ini adalah populasi nyamuk vektor.

Masalah lain dari paparan malation mengakibatkan gagal ginjal, kerusakan paru dan penurunan system kekebalan tubuh. Malation juga diduga mempunyai peran terhadap 28 gangguan, mulai dari gangguan gerakan sperma hingga kejadian hiperaktif pada anak. Tidak hanya itu, penggunaan solar sebagai bahan pengencer malation juga berbahaya. Hasil pembakarannya mengikat hemoglobin $(\mathrm{Hb})$ dalam darah dibandingkan oksigen. Racun hasil pembakarannya mengakibatkan radang paruparu, penyumbatan bronchioli serta iritasi dan produksi lendir berlebihan pada saluran nafas.

Pemanfaatan ikan pemakan jentik nyamuk adalah salah satu metode pengendalian vektor dengan cara biologi kontrol, dimana jenis ikan tertentu dimanfaatkan sebagai musuh alami atau sebagai predator nyamuk pada stadium jentik. Metode ini dinilai ampuh karena untuk mengendalikan nyamuk lebih efektif pada keadaan jentik serta tidak menimbulkan resiko lingkungan. Pemberian ikan pemakan jentik dapat dijadikan salah satu pilihan dalam pemberantasan vektor penyakit DBD. Karena ikan ini memiliki beberapa kelebihan yaitu tidak merusak lingkungan, tidak membahayakan kesehatan, tidak menyebabkan 
nyamuk menjadi kebal dan relatif lebih ekonomis.

Pemanfaatan ikan sebagai predator alami larva nyamuk adalah salah satu cara pengendalian secara biologi yang mudah untuk dilakukan oleh masyarakat. Metode pengendalaian secara biologis ini dapat mengurangi kepadatan larva nyamuk serta tidak menimbulkan masalah bagi kesehatan lingkungan.

\section{BAHAN DAN METODE}

Jenis penelitian yang digunakan adalah eksperimen semu (quasi experiment) dengan pendekatan Rancangan Acak Kelompok (RAK). Penelitian dilaksanakan di Laboratorium Biologi Universitas Muhammadiyah Parepare pada bulan Mei hingga Juni 2018. Populasi dalam penelitian ini adalah seluruh ikan pemangsa jentik. Sampel adalah kelompok ikan cupang (Betta spp) ukuran $\mathrm{S}(2,5-3,4 \mathrm{~cm}), \mathrm{M}(3,5-5 \mathrm{~cm})$ dan $\mathrm{L}(+5,5 \mathrm{~cm})$.

Pengambilan data primer dilakukan dengan metode observasi dengan melihat jumlah jentik yang habis dimangsa ikan cupang selama 24 jam setelah pemberian jentik. Hasil observasi diperoleh dengan mengamati kemampuan memangsa ikan cupang ukuran $\mathrm{S}, \mathrm{M}$, dan $\mathrm{L}$ dengan tiga kali percobaan, monitoring dilakukan setiap 5 menit selama 24 jam setelah pemberian pakan. Pengolahan data menggunakan Program SPSS 24. Analisis data dilakukan dengan menggunakan ANOVA. Data disajikan dalam bentuk tabel deskriptif disertai narasi.

\section{HASIL}

Pada Tabel 1 menunjukkan bahwa ikan cupang (Betta spp) pada ukuran S dalam 3 kali percobaan mampu memangsa jentik minimum 35,00 ekor, maksimum 37,33 ekor dengan ratarata memangsa 36,50 ekor jentik. Ukuran M dalam 3 kali percobaan mampu memangsa jentik minimum 43,50 ekor, maksimum 46,00 ekor dengan rata-rata memangsa 44,78 ekor jentik. Ukuran L dalam 3 kali percobaan mampu memangsa jentik minimum 48,50 ekor, maksimum 49,00 ekor dengan rata-rata memangsa 48,78 ekor jentik.

Pada Tabel 2 menunjukkan hasil uji ANOVA menggunakan metode RAL dengan derajat kepercayaan 95\% menunjukkan bahwa ada perlakuan yang berbeda nyata terhadap jumlah jentik yang dimangsa ikan cupang ukuran S, ukuran M dan ukuran L. Hal ini menunjukkan bahwa ukuran Betta spp memiliki kemampuan yang berbeda dalam memangsa jentik nyamuk Aedes aegypti.

Pada Tabel 3 menunjukkan menunjukkan bahwa perlakuan 1 (ukuran S) berbeda terhadap perlakuan 2 (ukuran M) dan perlakuan 3 (ukuran L). Begitu pula dengan perlakuan 2 (ukuran $\mathrm{M}$ ) berbeda dengan perlakuan 1 (ukuran $S$ ) dan perlakuan 3 (ukuran L). Demikian pula perlakuan 3 (ukuran L) berbeda dengan perlakuan 1 (ukuran S) dan perlakuan 2 (ukuran M).

\section{PEMBAHASAN}

Usaha pemberantasan nyamuk atau lebih tepatnya pengendalian populasi nyamuk yang sering dilakukan adalah dengan cara kimiawi. 
Salah satu pestisida kimiawi yang dianjurkan dalam mengendalikan nyamuk Aedes aegypti adalah tamephos (abate 1\%SG). Pestisida ini tergolong dalam senyawa organofosfat yang mempunyai toksisitas yang tinggi terhadap larva nyamuk dan rendah terhadap mamalia. Larvisida ini dikenal dengan merek dagang abate $1 \%$ berbentuk granula, mempunyai daya residu kurang lebih satu bulan pada tempat penampungan air. ${ }^{4}$ Pengendalian secara kimia ini dapat menimbulkan efek negatif berupa pencemaran lingkungan dan sulit terurai di alam. Pengendalian vektor nyamuk yang aman bagi manusia dan lingkungan tetapi tetap efektif dalam menekan dan mengendalikan populasi nyamuk vektornya dengan memutuskan mata rantai penularan dengan memberantas vektor penyebaran penyakit tersebut, salah satunya dengan pencegahan biologis melalui pemanfaatan ikan pemangsa jentik (larvivorous fish). ${ }^{5}$

Hasil penelitian diperoleh ikan cupang (betta spp) pada ukuran $\mathrm{S}$ dalam 3 kali percobaan mampu memangsa jentik minimum 35,00 ekor, maksimum 37,33 ekor dengan ratarata memangsa 36,50 ekor jentik. Ukuran $M$ dalam 3 kali percobaan mampu memangsa jentik minimum 43,50 ekor, maksimum 46,00 ekor dengan rata-rata memangsa 44,78 ekor jentik. Ukuran L dalam 3 kali percobaan mampu memangsa jentik minimum 48,50 ekor, maksimum 49,00 ekor dengan rata-rata memangsa 48,78 ekor jentik. Data tersebut menunjukkan bahwa ikan cupang ukuran $\mathrm{S}$ paling sedikit dalam memangsa jentik. Hal tersebut dikarenakan 2 ekor jentik yang dimasukkan ke dalam wadah percobaan 1 pada ukuran S sudah di gigit oleh ikan cupang namun lepas dan mati sehingga jentik tidak bergerak lagi dan kurang menarik perhatian ikan cupang untuk dimangsanya. Ikan cupang (Betta spp) pada umumnya lebih menyukai jenis makanan yang bergerak seperti jentik nyamuk, cacing darah dll.

Hasil uji statistik menggunakan metode RAL dengan $(\mathrm{p}=0,00)$ menunjukkan bahwa ada perlakuan yang berbeda nyata terhadap jumlah jentik yang dimangsa ikan cupang ukuran S, ukuran $\mathrm{M}$ dan ukuran $\mathrm{L}$. Hal berdasarkan perbedaan kemampuan memangsa, dimana ikan cupang ukuran L yang lebih agresif dalam memangsa jentik. Ini disebabkan oleh perbedaan ukuran badan dan besar ukuran mulut dari ketiga jenis variasi ikan cupang (Betta spp) yang membuat ikan cupang ukuran $\mathrm{L}$ dapat dengan mudah memangsa jentik karena ukuran mulutnya lebih besar dari ikan ukuran $\mathrm{S}$ dan $\mathrm{M}$.

Hasil penelitian Taviv menyatakan bahwa keadaan ikan cupang untuk menyerang mangsanya lebih besar dengan batas kemampuannya dalam waktu tertentu. Selain itu faktor ikan sendiri yang meliputi tingkat kemahiran (ketangkasan) dan ukuran tubuh akan mempengaruhi daya makan terhadap larva instar. ${ }^{6}$

Ikan cupang termasuk ikan predator agresif yang menggunakan penglihatan dalam mencari makan. Jika makanan cocok dengan ukuran mulutnya, maka ia akan segera 
menyambar makanan tersebut. Kebutuhan pakan harian ikan ditentukan oleh keagresifan jenis ikan, dengan demikian frekuensi dan jumlah pemberian pakan ikan yang bersifat agresif harus diperbanyak (Effendi, 2002). ${ }^{7}$

Ikan cupang (Betta spp) termasuk ikan pemakan daging (carnivora) berdasarkan macam pakan yang dimakannya, dan hanya mengkonsumsi satu jenis makanan (monophagus) berdasarkan spesialisasi kebiasaan makannya. Masa aktif ikan cupang (Betta spp) dalam mengambil makanan (feeding periodicity) selama 24 jam adalah terus-menerus ketika larva nyamuk diberikan. Feeding periodicity pada ikan cupang yang aktif pada siang hari dimulai pada siang hari sampai matahari terbenam. ${ }^{8}$

Feeding periodicity berhubungan dengan suplai makanan dan lingkungan. Jika kondisi lingkungan buruk, feeding periodicity dapat berubah, bahkan menyebabkan terhentinya pengambilan makanan. ${ }^{7}$

Ikan cupang (Betta spp) mampu memakan jentik nyamuk Aedes aegypti sebanyak 100 ekor selama 1 jam. Hal ini sesuai dengan penelitian yang dilakukan oleh Anggit (2016) yang menyatakan bahwa Ikan cupang (Betta spp) mampu memangsa rata-rata 83,33 ekor jentik Aedes aegypti dalam waktu 6 jam.

Hasil penelitian Yogyana (2013) menyatakan kondisi lingkungan dapat mempengaruhi keberadaan larva. Pemeliharaan ikan predator seperti ikan cupang dapat menurunkan jumlah jentik. Karakteristik ikan cupang dalam memangsa larva adalah ikan cupang langsung memakan jentik, tidak mengubah rasa air. Cara tersebut merupakan salah satu alternatif pencegahan terhadap penyakit demam berdarah. ${ }^{9}$ Hasil penelitian Taviv (2011) menyatakan hasil intervensi dengan pemanfaatan Ikan Cupang (Betta sp.) plus pemantau jentik lebih efektif meningkatkan Angka Bebas Jentik (ABJ) dibandingkan hanya dengan pemantau jentik. Namun predator larva Aedes aegypti di lapangan masih jarang ditemukan padahal predator larva Aedes aegypti ini selain dapat menekan perkembangan larva juga dapat dipelihara sebagai ikan hias misalnya ikan cupang. ${ }^{10}$

Peran kesehatan masyarakat dalam pemberantasan sarang nyamuk sangat penting untuk menurunkan angka kejadian DBD. Saat ini untuk memberantas nyamuk sebagian besar masyarakat melakukan pemberantasan secara kimiawi, dimana efek yang di timbulkan dari penggunaan bahan kimia tersebut sangat berdampak buruk bagi manusia maupun lingkungan. Sehingga dari penelitian ini dapat dijadikan rujukan dalam pemberantasan jentik nyamuk bahwa ikan cupang ukuran $\mathrm{L}(5,5 \mathrm{~cm}$ keatas) terbukti efektif dapat menurunkan populasi jentik nyamuk sehingga penyakit DBD dapat dicegah dengan pemeliharaan ikan predator jentik nyamuk yang telah digunakan dalam penelitian ini.

Ikan cupang (Betta spp) juga tidak menimbulkan efek samping bagi masyarakat karena tidak mengancam kesehatan dan keselamatan manusia serta tidak merusak 
lingkungan sekitar sehingga dibutuhkan upaya untuk menyampaikan dan memberitahu kepada masyarakat akan manfaat ikan cupang (Betta spp) sebagai predator alami jentik nyamuk Aedes aegypti. Masyarakat juga dapat membudidayakan ikan cupang (Betta spp) sebagai predator alami juga sebagai ikan hias sehingga dapat bernilai ekonomis.

\section{DAFTAR PUSTAKA}

1. Departemen Kesehatan RI. 2003. Survey $D B D$. DepKes RI. 50 Hlm.

2. Faudzy, H. \& Hendri, J., 2015. Indeks Entomoogi dan Kerentanan Jentik Aedes aegypti Terhadap Temefos di Kelurahan Karsamenak Kecamatan Kawalu Kota Tasikmalaya. Vektora : Jurnal Vektor dan Reservoar Penyakit, 7, pp.57-64.

3. Sarwar, M., 2015. Control of Dengue Carrier Aedes Mosquitoes (Diptera : Culicidae) Jentike by Larvivorous Fishes and Putting It into Practice Within Water Bodies. Criteria to Quantify the Efficacy of Larvivorous Fish., 1(4), pp.232-237.

4. Srisasi G. H. D. Ilahude, dan W. Pribadi. 2003. Parasitologi Kedokteran. Balai Penerbit FKUI. Jakarta.

5. Dai L dkk. 2014. Perbedaan Ikan Hias Cupang (Betta Spp) Dan Ikan Hias Koi (Cyprinus Carpio) Dalam Memakan Larva Aedes Segypti.

\section{KESIMPULAN DAN SARAN}

Semakin panjang ukuran badan ikan cupang (betta spp) maka semakin banyak memanga jentik nyamuk Aedes aegypti sehingga dapat dijadikan sebaga biokontrol dalam memberantas nyamuk Aedes aegypti. Disarankan untuk penanggulangan nyamuk Aedes aegypti dapat dilakukan dengan cara biologi yaitu dengan memanfaatkan ikan pemangsa jentik seperti ikan Betta spp.

6. Taviv Y. 2007. Efektivitas Ikan Cupang (Ctenops vittatus) dalam Pengendalian Larva dan Daya Tahannya terhadap Temephos (Uji Laboratorium dan Lapangan). Jurnal Ekologi Kesehatan Badan Litbang Depkes RI Vol: 6, No.2 Litbangkes Jakarta.

7. Effendi M. I . 2002. Biologi Perikanan. Yayasan Pustaka Nusatama. Yogyakarta.

8. Zen S. 2012. Biokontrol Jentik Nyamuk Aedes Aegypti Dengan Predator Ikan Pemakan Jentik Sebagai Pendukung Materi Ajar Insekta. jurnal pendidikan biologi. (https://scholar.google.co.id)

9. Yogyana L. 2013. Hubungan karakteristik lingkungan kimia dan biologi dengan keberadaan larva aedes aegypti di wilayah endemis DBD di Kelurahan Kassi-Kassi Kecamatan Rappocini Kota Makassar tahun 2013.

10. Taviv Y. 2011. Pengendalian DBD Melalui Pemanfaatan Pemantau Jentik Dan Ikan Cupang Di Kota Palembang. Health Science Journals: Indonesia. 


\section{LAMPIRAN}

Table 1. Jumlah minimum, maximum dan rata-rata jumlah jentik yang dimangsa ikan cupang (betta spp) dalam 3 kali percobaan.

\begin{tabular}{lcccc}
\hline & \multicolumn{4}{c}{ Jumlah Jentik Yang Dimangsa } \\
\cline { 2 - 5 } & Std. Deviation & Minimum & Maximum & Rata-rata \\
\cline { 2 - 5 } Ukuran S & 1.30150 & 35.00 & 37.33 & 36.50 \\
Ukuran M & 1.25085 & 43.50 & 46.00 & 44.78 \\
Ukuran L & .25423 & 48.50 & 49.00 & 48.78 \\
\hline
\end{tabular}

Table 2. Perbedaan jumlah jentik yang dimangsa ikan cupang (betta spp) ukuran S, ukuran M dan ukuran L.

\begin{tabular}{lrrrrr}
\hline & Sum of Squares & Df & Mean Square & F & \multicolumn{1}{c}{ Sig. } \\
\hline Between Groups & 235.220 & 2 & 117.610 & 106.173 & .000 \\
Within Groups & 6.646 & 6 & 1.108 & & \\
\hline Total & 241.866 & 8 & & & \\
\hline
\end{tabular}

*ANOVA test

Table 3. Hasil Uji Duncan

\begin{tabular}{cccccc}
\hline Duncan $^{\mathrm{a}}$ & Variasi Ukuran Panjang & & \multicolumn{3}{c}{ Subset For Alpha $=0.05$} \\
\cline { 3 - 5 } Badan Ikan Cupang & $\mathrm{N}$ & 3 & $36.5000 \mathbf{a}$ & & 3 \\
\cline { 4 - 6 } & Ukuran S & 3 & & $44.7767 \mathbf{b}$ & \\
Ukuran M & 3 & & & $48.7767 \mathbf{c}$ \\
Ukuran L & & \multirow{2}{*}{1.000} & 1.000 & 1.000 \\
Sig. & & &
\end{tabular}

Means for groups in homogeneous subsets are displayed.

a. Uses Harmonic Mean Sample Size $=3.000$. 